KEY WORDS

Industrial policy

Industrial enterprises

Industrial organization

Regionalism

Chile - Uruguay
CEPAL REVIEW 91. APRIL 2007

\section{Mirrors of change: industrialists \\ in Chile and Uruguay}

\author{
Andrés Rivarola
}

$\mathrm{T}$

his study examines institutional changes in Chile and Uruguay between the mid-1960s and late 1990s. It seeks to tie together the macro and micro levels in order to observe how institutions working with local and global issues interact or conflict from the perspective of two industrialists' associations, the Manufacturers Association (SFF) in Chile and the Chamber of Industry of Uruguay (CIU). From this vantage point, the study analyses how the organizations' 'logic of appropriateness' has altered since the 1960s, with the expectation of identifying changes in the way sources of legitimacy interact at the global, regional and national levels. To make the process of change more visible, the study concentrates on two years, 1966 and 1998. It also tries to identify new dimensions of comparison between the development processes of Chile and Uruguay.
Andrés Rivarola

Researcher associated with the Department of Economic History and the Institute of Latin American Studies at Stockholm University

$\rightarrow$ andres.rivarola@ekohist.su.se 


\section{I}

\section{Introduction}

Since the 1990s, an increasing body of work has been produced by institutionalists who regard rational choice as too narrow a perspective for explaining conflicts of interest in society (Hart, 1995). One aspect of this approach derives from organizational theory in the social sciences, among whose starting points is the work of Selznick (1949). Selznick maintained that organizations were not "rational creatures" but vehicles for values, and argued that organizational values and standards were transmitted through the institutional environment in which they were embedded. From this perspective, an organization is defined as the function of the legitimated interests transmitted through the 'institutional environment'. This environment is characterized by the creation of institutional rules and requirements to which organizations must conform if they are to be legitimated. An institution is seen as a 'social pattern' governed by particular rules of thought and behaviour, and the institutionalization of an organization takes place when it sets out to validate itself by imitating other models deemed superior (Powell and DiMaggio, 1991). This is of a piece with what March and Olsen (1989) called the 'logic of appropriateness', according to which it is possible to enforce rules without direct coercion, by imposing codes of behaviour.

Following this line of thinking, we shall look at industry associations as an institutional meeting point where the interaction of three institutional levels, the national, the regional and the global, can be observed. The boundaries between these levels are not fixed, so labelling organizations or institutions as belonging to one of them does not mean they cannot also act on the others. This study argues that there has been a change in the national institutional environment since the Second World War. The influence of world and regional institutions has increased during this period, a process that can clearly be identified in the globalization of the 1990s. Some refer to this as Empire (Hardt and Negri, 2000); we prefer to speak of the spread of a 'world culture' promoting standardized values and models. These have as their core a 'technical' (rational) outlook and a culture of human rights (Boli and Georg, 1999) promoted by a number of international bodies, centring on the United Nations system. Regionalism has been part of this process, but has taken place at a meso level, as a way of confronting globalization (Hettne and Inotai, 1997). All this has increasingly eroded nationStates, the result being that new sources of 'legitimacy' have emerged from non-national 'spheres of authority' (Rosenau, 2003).

A second hypothesis is that structural changes have different effects at the local level, since each institutional environment creates its own forms of 'institutional isomorphism' (mimetism) or resistance. Both Chile and Uruguay display their own forms of adaptation, each having its peculiar local mix of continuity and change. Like any comparison, of course, this one will have different nuances depending on the questions, variables and actors chosen. In any event, the hope is that the conclusions of this study will add to our understanding of institutional change and continuity, both between the countries and between micro- and macro-level institutions. It is also hoped that the approach of this study will reveal other factors that can serve to explain the different paths taken by development in Chile and Uruguay. For decades, the two countries were South America's most stable democracies, with a strongly developed State machinery and vigorous industrial sector growth. In the 1990s, once again under democratic rule, Chile pulled well ahead of Uruguay as a 'successful' model of 'how things should be done' in a globalized world.

Following the present introductory section, this study undertakes a brief review of the industrial policies and modes of organization that provide the historical background to each institutional environment (section II). It then focuses on the 1960s, exploring the 'logic of appropriateness' in the first institutional wave of world culture (section III). Section IV reviews what has been called here the 'military interlude' as the basis for a better understanding of certain patterns of change in the 1990s. Section V analyses the 1990s and section VI, lastly, presents some conclusions.

The military interlude meant an interruption in the influence of certain international bodies, an influence that resumed in a context of market liberalization and the renewed sway of world culture. To make the comparison plainer, the same structure of analysis was followed for the 1960s and the 1990s. 


\section{II}

\section{Early industrial organization and policies}

The first effort at organization by Uruguayan industrialists came with the creation of the Industrial League in 1879 (Jacob, 1981). This was short-lived and faced hostility from supporters of free trade: agrarian landowners and the business elite in Montevideo. As the word 'League' suggests, this was a loose conglomeration of different groups of fairly weak associations. The debate about a new customs law was to trigger the establishment of the Uruguayan Industrial Union (UIU) in 1898 (Ferrando, 1989), mobilizing the old members of the League in defence of protectionist ideals. The industrial sector was coming up at this time owing to the growth of industrial activity and the increasing influence of José Batlle y Ordóñez and 'Batllismo'. ${ }^{1}$ Most UIU members were owners of small workshops, since there were very few large manufacturing plants in the country. The ranks of the UIU did not include any of the country's leading families, but different immigrant groups were strongly represented (Beretta Curi and Etcheverry, 1998). Another point that should be stressed is how little State involvement there was when industrialists began to organize. However, many of the association's younger members went on to join the ranks of the country's leading politicians. One example is Batlle y Ordóñez himself, who was a journalist in the Industrial League, and another was José Serrato, an engineer in the UIU. ${ }^{2}$ Business leaders were included in the decision-making process as Batllism gained ground, and this gave rise to organizational changes designed to ensure effective business representation. Thus, in 1914 the Chamber of Industry of Uruguay was founded with the aim of creating a more centralized and efficient structure. The name UIU was retained, while some documents and statements were signed under the name of 'Chamber of Industry of Uruguay, leading corporation of the Union of Industrialists of Uruguay'. Only in 1973 was the Chamber of Industry of Uruguay appellation formalized as the organization's sole name.

\footnotetext{
${ }^{1}$ Batlle was President of Uruguay in 1903-1907 and 1911-1915.

${ }^{2}$ Serrato was President of Uruguay in 1923-1927.
}

The situation in Chile was very different. By the late nineteenth century, the Pacific War had already generated strong State demand for heavy industry. Before the conflict, the Chilean manufacturing sector comprised a few isolated factories and a range of small workshops. With large mineral deposits secured, both mining and railway construction stimulated the establishment of heavy industries because of their growing requirements for locomotives and equipment (Kirsch, 1977). Chilean industry thus emerged in close association with the State, under tariff protection or direct government ownership. By contrast with the situation in Uruguay, there was active official support for the creation of the Manufacturers Association (SFF). The finance minister asked the National Society of Agriculture (SNA) to support the creation of an association that would represent the interests of Chilean manufacturers (Ceppi, Sanhueza and others, 1983). It was thus that the Manufacturers Association came to be created in 1883 under State auspices (Zeitlin, 1984) - a modest organization that had to hold its meetings on the premises of the SNA (Apey, 1988). The support of the SNA shows that, despite the growth of industry, there were no serious conflicts between rural and industrial interests.

The role of the SFF grew in importance when industrialization became a State policy, conducted through bodies such as the Production Development Corporation (CORFO), created in 1939. It is no coincidence that the initiative of creating the SFF was a 'top-down' one issuing from the State, and that the State also centralized industrial policies through CORFO, whose technical pre-eminence was respected and emulated by businesses. This can be seen as part and parcel of two characteristically Chilean institutions: elitism and meritocracy. Chile isolated itself from the civil wars of the Southern Cone, giving continuity and strength to a hierarchically structured State apparatus dominated by an oligarchy, to a meritocratic State bureaucracy and to a political class with an interest in a strong State.

The consolidation of the Uruguayan State, and of its oligarchy, came much later. This might explain why the CIU was a 'bottom-up' creation. Although it became institutionalized during the Batllista period, contacts 
with the State were as fragmented as industrial policies, where these existed. Leaving aside Batlle's towering presence, what Uruguay had were not 'policies' but 'shoves' delivered by the leadership of the moment and personal networks. This is why caudillism and clientelism emerge as predominant institutions. The difference between caudillism (Uruguay) and elitism (Chile) is that while the former has more to do with

\section{III \\ The 1960s}

\section{Uruguay}

During the first half of the twentieth century, the CIU turned itself into a solid and increasingly influential organization, a process that was associated with the rapid advance of industry and the strengthening of industrial groups. Approximately half of today's Uruguayan industrial groups were formed between 1933 and 1954 (Zurbriggen, 1999). In 1966, the CIU had a membership of some 20,000 companies with around 500,000 employees (El Día, 1966). The General Assembly was the most representative body, electing board members by means of lists rather than as individual candidates. A great many members came from sectoral industry associations, which were required to see that all their members were registered as members of the CIU, although this was not strictly enforced. The industry associations also had nonvoting representatives on the board. Furthermore, one criterion for selecting candidates was that they should represent people from different sectors with previous experience in an industry association. Each election replaced a third of board members, so that change was gradual. All this added up to a generally non-confrontational atmosphere, since the different industry associations (and the major companies) usually agreed upon a common list of candidates. This system assured stability in the running of the CIU whilst reducing internal debate and participation. Thus, the dominance of large firms gave the CIU the image of a 'big industrialists' club'. At the 1966 General Assembly, just 49 companies participated in the election (CIU, 1966). Besides the industry associations, the board had a great deal of influence, extended through the working 'charisma', which operates horizontally across social groups, the latter is based on a more vertical structure in which a hierarchical order is segmented by way of dominant groups. None of this means that the salient features of one case are not to be found in the other; we are simply pointing out what appear to be the characteristics of each institutional environment.

committees. Committee chairmen were board members, but had to be approved by the General Assembly.

Most of the CIU annual report for 1966-1967 was given over to information about contacts with public authorities regarding customs matters or exchange rates (CIU, 1966). It is unsurprising, then, that the two national units most often mentioned were the Ministry of Industry and the (State-owned) Banco de la República Oriental del Uruguay. The CIU offered little in the way of services and did not pay much attention to small and medium-sized enterprises (SMEs); this reinforced its image as an elitist organization and may have contributed to the low turnout in internal elections. As for the profile of board members, the annual report referred to above shows that about half had no academic qualifications (a profile similar to that of industry ministers at the time). Of those who did have such qualifications, most lacked any training in economics or technological disciplines. There was a retired general, a doctor and two lawyers. Two engineers and an accountant represented professions perhaps more allied with manufacturing. This lack of professionalism was a characteristic shared with the Uruguayan civil service (CIDE, 1989). The country had no training plan for officials, and when something along these lines was implemented, little account was taken of the private sector. Companies continued to be familyowned (owners were usually first- or second-generation immigrants) and produced consumer goods for the local market. Although some had grown into oligopolies (with State protection), they had no incentive to change. Sons succeeded fathers with no change in management profiles, which is perhaps why most board members were owners rather than professional managers. Nor 
was there any interest in change: contacts with the State guaranteed business and the importance of the CIU was not at issue.

\section{(a) The national level}

Most CIU contacts were with the executive branch, and especially the industry ministry, which industrialists lobbied for various types of State intervention. The ministry had little in the way of industrial policies, however, and lacked the technical capabilities and powers of coordination to implement policies efficiently. If professional training is taken as an indicator of 'technical capacity', the backgrounds of ministers are revealing. Between 1907 and 1996 there were just one economist, five accountants and four engineers; the rest were lawyers or people without academic qualifications (MIEM, 1997). Few came from the private sector. The profile of ministers suggests that party affiliation outweighed technical capabilities. Another important body in the State was the Banco de la República Oriental del Uruguay, which had the monopoly of the currency market and controlled the country's system of differentiated exchange rates. A key division in the bank was the Auditing Unit for Currency Operations and Capital Transfers Abroad. Although the position of the bank declined with the liberal reforms of the early 1960s, it was still playing an important role in the middle of the decade.

Other points of intersection between industrialists and the State were the different committees that acted as meeting places between the public and private sectors. Although these were not often mentioned in CIU reports, their activities may serve to show the areas in which businesses exercised influence. Two examples are the Rebate Advisory Committee and the Tariff Board. Although the CIU had little influence on policymaking, it had a great deal to say about rebates and import tariffs. One particularly interesting aspect of the interaction with the State was the Uruguayan version of developmentalism, promoted by the Investment and Economic Development Committee (CIDE) created in January 1960. This committee had high-grade technical staff and its work had an effect on industry. Contrary to the usual perception of industrialists as 'clientelist' or 'short-termist', there were serious efforts by the sector to offer proposals of its own that would harmonize with the work of the CIDE. The most important of these was the creation of the Coordinating Committee for Economic Development (COMCORDE) in 1963. Widespread support for the creation of the CIDE was a fundamental source of inspiration for
COMCORDE members. ${ }^{3}$ Approximately 50 technical specialists passed through this coordinating committee, one of the first organizations in the country to recruit economists. From the dissolution of the CIDE in 1967 to its own closure in 1981, COMCORDE produced a series of indicative planning studies and sectoral analyses. Because the CIDE was a modernizing venture with a wide-ranging long-term vision, the CIU firmly supported it. It is also clear, though, that the CIDE was very dependent on the State. When the latter lost interest in developmentalism, businesses were unable to sustain the new approach and went back to their old ways.

\section{(b) The regional and global level}

Most references to non-Uruguayan bodies in the 1966-1967 annual report concern regional organizations, especially the Latin American Free Trade Association (LAFTA), created in 1961. Businesses were initially somewhat apathetic about this initiative, in which they participated at the behest of the government rather than on their own initiative (Finch, 1973). Nor were official efforts to engage the private sector very enthusiastic. As for the CIU, Astori (1980) argues that the Chamber perceived the free trade area more as a threat to Uruguay's protectionist system than as a change in the international context that would help increase industrial exports. Unsurprisingly, then, the Chamber did not participate in the preparatory committees for the LAFTA agreement. By 1966 the Chamber's scepticism had abated markedly: it was argued that LAFTA was of critical importance for Uruguay and that more attention had to be paid to the subject of integration and the adoption of a long-term policy. Apart from the trade aspect, industrialists were interested in the new types of international business networks that developed around the negotiations: for example, the Association of Latin American Industrialists (AILA). Regional bodies of this type did much to promote new kinds of business identity that played a key role in the adoption of a positive stance towards LAFTA.

Despite the changing attitude of the CIU towards integration, its organizational structure did not alter much $^{4}$ and LAFTA hardly rated a mention in the 19661967 annual report, perhaps because the CIU never

\footnotetext{
${ }^{3}$ Interview with Walter Luciardo Aznares, technical secretary of the CIU in 1966.

${ }^{4}$ Interview with Carlos Folle, head of the CIU in 1966.
} 
explicitly adopted a pro-export outlook. Only in the mid-1970s was an external trade committee created in the CIU, with much internal discussion of the progress made by sectoral meetings, supplementary agreements and regional programmes for businesses. Although the CIU had a low profile in the LAFTA process, sectoral industry associations and large companies were more active. Because the State did not have the tools it needed to obtain the requisite information, businesses played a key role in the preference or concession issues negotiated by Uruguay with other countries. Requests for information were routed through the CIU or directly through sectoral associations. From this point of view, it would be true to say that they exercised influence. Another part of the LAFTA process related to the work of the Association of Latin American Industrialists (AILA). Having been fairly enthusiastic to begin with, in 1966 the CIU turned sceptical, arguing that AILA tended to be over-bureaucratic and that its members did not have the financial capacity to make it work (La Mañana, 1966).

The CIU 1966-1967 annual report mentions just two international forums (the World Wool Congress and the International Labour Conference) in a way that indicates some kind of engagement. There are also two mentions of the Uruguayan Technical Standards Institute (UNIT), founded in 1939. Although this was a Uruguayan body (private but State-backed), it quickly began to act as a representative of international institutions in its work with quality standards. Businesses had little interest in quality improvements, so UNIT was barely mentioned. It is interesting to note that the international organization that was perhaps most important to the industrial sector, the Inter-American Development Bank (IDB), was not mentioned in this annual report. This may be due to the lack of formal contact between the CIU and the IDB, which essentially operated through the State and, most particularly, the Banco de la República Oriental del Uruguay. On the whole, there was little that the CIU might have written about regional or global organizations in that period.

\section{Chile}

The technical profile of SFF executive committee members gives a good idea of the difference between the institutional settings of Chile and Uruguay. Most were professionals, invariably engineers. Foreign qualifications do not seem to have been common in Chile either: just one committee member held them. Most of the members held positions in the State apparatus, examples being the SFF representatives on the boards of CORFO and the Central Bank of Chile. Something the SFF had in common with the CIU was that the members of its executive committee came essentially from large firms. On the other hand, managers were better represented on the SFF board, perhaps because Chile had a more highly developed industrial sector where professional managers (as opposed to traditional owners) were more likely to represent firms. The strong presence of large companies (represented by owners or managers) in the SFF leadership heightened the organization's image as a representative of business groups. What Arriagada (1970) called the "oligarchic tendency" was entrenched by statutes that did not allow voting by lists, thus preventing the creation of electoral groups. At the same time, industry associations had one vote each on the executive committee, which did not reflect their true weight in the SFF. For example, the Association of Metallurgical and Mechanical Engineering Industries (ASIMET), representing $17.5 \%$ of members, had just one seat on the committee. Furthermore, $28 \%$ of executive committee members were honorary and former chairmen had a seat for life. According to Arriagada (1970), these elements combined to favour oligarchic tendencies that benefited large industrial groups.

\section{(a) The national level}

Although LAFTA was the organization that received the most mentions in the SFF 1966-1967 annual report (SFF, 1966), most of the association's contacts were with local organizations as a group, and particularly State ones, especially CORFO, the Central Bank and parliament. In relation to CORFO, this annual report refers to contacts in which the SFF called for lower tariffs on imports of industrial equipment. Another reference is to complaints by regional industry associations about difficulties with credits and debt repayments. These representations were made to the SFF leadership and then relayed directly to CORFO. Regarding the Central Bank, import quotas were an important concern. This also came up in the debate on an export promotion law. As for interaction with parliament, to which it gave higher priority than the CIU, the SFF had an advisory group on parliamentary matters which members could approach for advice and contacts with politicians. SFF (1966) shows that the association expressed its views on amendments to the law giving special tariff treatment to the Department of Arica. Parliament was also mentioned in connection with the law to promote the automobile industry in Chile and constitutional amendments to 
"weaken effective private property rights". This was partially related to an outspoken debate on agrarian reform.

Regarding participation on State committees, the SFF, like the CIU, had an institutionalized role in the import substitution structure. It was represented on State bodies such as the Banco del Estado, CORFO and the General Board of Customs, where business leaders concerned themselves mainly with specific issues such as prices, exchange controls or specific laws. Beyond this involvement, industrialists did not appear to have any particular stance of their own on the economy. Each was basically concerned with its own sector, leaving the initiative of producing economic and social policies to the State. This did not mean that they did not try to create their own analytical instruments. In 1954, a group of businesses founded the Chilean Institute of Rational Business Management (ICARE). Those behind the initiative saw themselves as "progressive employers' and most of their leaders were from the SFF (Empresa, 1968). At the same time as ICARE was showing it had the initiative to create research centres of its own, there were signs of close interaction with the State. Very well-known officials and supporters of the Christian Democratic Party, such as Raúl Sáez and Gabriel Valdés, became presidents of the institute. Until 1968, almost all ICARE chairmen had held public office, most as ministers or ambassadors.

\section{(b) The regional and global level}

As in the case of the CIU, the international body most often mentioned in the SFF 1966-1967 annual report was regional in character: LAFTA. The participation of the SFF in the LAFTA system was also similar to that of the CIU: both gave or withheld their approval to negotiated products. In the Chilean case, it is surprising that LAFTA was mentioned more often than CORFO, since industrialists were not exportoriented. One reason could be that Chile was among the most active countries in the integration debate. It is no coincidence that the headquarters of the Economic Commission for Latin America (ECLA) ${ }^{5}$ was located in Santiago, the Chilean capital, or that several of that organization's great thinkers were Chilean. Industrialists were also enthusiastic about ECLA initiatives, as was LAFTA. In 1961, at the annual meeting of the

\footnotetext{
${ }^{5}$ Now the Economic Commission for Latin America and the Caribbean (ECLAC).
}

SFF National Industry Convention, firm support was expressed for the integration process and the decision was taken to create a free trade committee in the SFF, whose work would be coordinated jointly with the government. Opinion was not unanimous, however, as companies in the light industry segment (comprising most of Uruguayan industry) rather tended to oppose the idea from fear of regional competition (Mikesell, 1961). Despite this, the SFF was one of the driving forces behind LAFTA. This perhaps ties in with its image as an elite organization, although many of the enthusiasts were also jealous of their tariff protections. LAFTA had another dimension that transcended economic calculations.

Businesses were highly dependent on a State that was making major advances in the industrial sector. This was viewed with suspicion by the SFF leadership, whose position was weakening owing to the successes of CORFO and its 'public-sector entrepreneurs'. In this context, the declarations made in support of the private sector by regional integration organizations and their associated business networks acted as a counterweight to growing 'statism'. The strategy of Chilean business leaders was to pursue ideological strength and legitimacy through these organizations, in order to promote the idea that Chile needed the private sector. Perhaps this is why the SFF showed itself more favourable to AILA than the CIU; even as the CIU was criticizing AILA as a bureaucratic and unnecessary organization, the SFF was making more positive statements in support of a higher level of institutionalized private-sector involvement in the negotiations. The IDB, under the leadership of a Chilean, Felipe Herrera, provided Chile with a great deal of support but had little contact with the SFF. The SFF 1966-1967 annual report tells of the donation of a valuable economics library to the SFF by the IDB and describes the participation of members of the Chilean business community in a conference on regional integration financed by the bank. The SFF seems to have had rather more contact with the IDB than did the CIU, but this should not be put down exclusively to a specific outlook among businesses. In fact, most regional and global contacts were handled by the State. As early as the 1950s it began to send officials to study abroad and strengthened ties with universities in the United States and Europe. Meanwhile, Chile was very popular with international organizations, receiving more support than any other country in terms of dollars per capita (El Mercurio, 1966). A major impetus was provided here by the interaction with ECLA, the international body most influential in spreading the technocratic 
approach in government and business circles through indicative planning. The ingredients of the first wave of world culture can clearly be seen at work in Chilean institutions.

\section{IV}

\section{The military interlude}

The coup in Uruguay was launched by a constitutional president with military support, so that there was continuity in economic policies and leadership. As Faroppa (1982) explains, the bases of the model from 1973 onward were the same as those adopted shortly before by the civilian government, i.e., the 1973-1977 National Development Plan, produced by the Office of Planning and the Budget. The regime's economy minister himself, Alejandro Vegh Villegas, has explained that when he took up the position he based his actions on the plan prepared by Ricardo Zerbino and Alberto Bensión. ${ }^{6}$ Both Zerbino and Bensión later became ministers in post-dictatorship governments, so that it is reasonable to speak of continuity in economic policy design. Two of the main initiatives of Vegh's ministry had already been signed when he came to power: the Argentine-Uruguayan Economic Co-operation Agreement (CAUCE) and the Protocol on the Expansion of Trade between Uruguay and Brazil (PEC). These agreements were very important for the manufacturing sector, and the CIU in particular, as it acquired an institutionalized position in the new trading system with a monopoly on the issue of certificates of origin for exports under CAUCE and PEC, thus obtaining a new and very substantial source of revenue.

When the army seized power in Chile, the State controlled almost the whole of the banking system, over 323 firms had been confiscated or were under State supervision, and large tracts of land were being

\footnotetext{
${ }^{6}$ Interview with Alejandro Vegh Villegas, Minister of Economy in 1974-1976 and 1983-1985.
}

administered by cooperatives. During 1972, exports fell to their lowest level yet, inflation reached $600 \%$ and export revenues were $80 \%$ dependent on copper. Private-sector associations saw themselves as part of the driving force behind a victorious revolution and the new regime (Campero, 1984). They continued to give their support even though they were soon pushed to the sidelines by what Silva (1996) called the "radical neoliberal coalition", and even when sharp tariff cuts forced large sectors of industry into bankruptcy. The severe economic crisis of 1982 finally removed this tendency, which was replaced by a pragmatic neoliberal group in which business had a greater voice. After their testing experiences with both the Popular Unity government and the 'Chicago boys', businesses began to develop their own technical capabilities, acquiring a shared language with the State technocracy.

In Uruguay, meanwhile, certain traditional features remained. After more than a decade of military government, economic policies culminated in an instrument designed to create a base of clientelist support for the men of the dictatorship (Stolovich, Rodríguez and Bértola, 1996). Owing to the structure of the military junta itself, and by contrast with Pinochet's centralism, each section of the armed forces had a significant power of veto, which created opportunities for establishing pressure groups and reduced the influence of State experts on public policy implementation. The military did not succeed in consolidating caudillo figures. What they did was to create sectoral leaderships that interfered with the operation of centralizing mechanisms and led to clientelism. Changes were few, among industrialists as elsewhere. 
$\mathrm{V}$

\section{The 1990s}

\section{Chile}

The environment was the subject treated at greatest length in the SFF 1998-1999 annual report. This was an issue that was almost non-existent in the 1960s and that began to be taken seriously in 1992, with the appearance of the first State environmental programme, the Metropolitan Region Decontamination Plan. A few years later there were 10 national programmes. Although the environment became a very important issue for industrialists, it only occupied a small portion of SFF manpower. One reason for this was the substantial technical support provided by member firms. The task of the SFF, therefore, was mainly to monitor the legislative process through special committees in which company experts participated. ${ }^{7}$ A second issue addressed in this annual report was that of international relations and foreign trade. The issue of foreign trade gained in importance, it might be said, in two ways: through participation in trade negotiations and through the work done with trade promotion organizations (services). The SFF became the 'technical secretariat' for the private sector where trade negotiations were concerned. ${ }^{8}$ A third set of issues was dealt with by the social development section, which did not exist in 1966; the most important of these derived from the association's traditional commitments, such as industrial education. By 1998, the SFF was running 18 technical secondary schools nationwide and had become one of the country's intermediate technical training organizations (OTIC) by virtue of a State programme run by the National Training and Employment Service (SENCE). The 1997-1998 annual report also refers to the Small Business Development Corporation (PROPESA), which provided small enterprises with soft loans and ran educational programmes with the help of resources from the Solidarity and Social Investment Fund (FOSIS), allocated by CORFO.

The composition of the 1998 executive committee, as compared with that of 1966 , evinces two tendencies:

\footnotetext{
${ }^{7}$ Interview with Aníbal Mege Thierry, head of the SFF environmental section.

${ }^{8}$ Interview with Aníbal Mege Thierry.
}

greater professionalization and concentration in economic areas. In $1998,85 \%$ of the committee was composed of professionals, as against 64\% in 1966 . Most of them were engineers or what in Chile are called commercial engineers. In 1998 there were also more foreign-educated members, almost all of them graduates of universities in the United States. Between 1966 and 1998, the proportion of managers on the committee rose from $63 \%$ to $70 \%$, while the share of members holding public office fell from $55 \%$ to $30 \%$. Another characteristic was that more members had ties to companies belonging to the major industrial groups.

\section{(a) The national level}

The organization most often mentioned in the SFF 1997-1998 annual report was the National Environment Commission (CONAMA). Another public body mentioned in connection with environmental issues was the Metropolitan Environmental Health Service (SESMA), which was responsible for implementing the Metropolitan Region Decontamination Plan. This was a matter of the greatest importance for businesses, as the emissions of a number of firms were to be monitored by public bodies. The role of SESMA was rather reactive in nature, since CONAMA was the driving force behind the new regulations.

As regards foreign trade, there was an explosion of services provided mainly by the Chilean State, which had improved its coordination mechanisms both internally (Interministerial Committee for International Economic Negotiations) and externally with the private sector (Private Sector Participation Committee). A key organization was the Office of International Economic Affairs (DIRECON), which came under the Ministry of Foreign Affairs. As Silva (2001) explains, the relationship between DIRECON and the SFF became a key link in public-private interaction, as they were both coordination units in their respective areas. Another State UNIT with close links to the SFF was the Export Promotion Bureau, known as ProChile, which helped Chilean businesses enter international markets. Although CORFO is hardly mentioned in the 1997-1998 annual report, many of the governmental or paragovernmental bodies appearing there were 
part of the network financed by CORFO. During the first half of the 1990s, the total amount of resources transferred through public financing instruments could be put at some US\$ 470 million (Muñoz, 1997, p. 8). Although public assistance programmes were criticized for being slow or inefficient, they were not spurned by the representatives of the SFF, which indeed had benefited financially from the system. The position of the SFF is reminiscent in a way of that attending the creation of CORFO, when it was accepted that the State should take responsibility for a large proportion of business development policies, trusting that this would not undermine private property rights. Mutual understanding with the State could also be seen in the increasingly technocratic nature of both the public and the private sectors. Almost all CORFO programme directors were economists, many of them graduates of United States universities. The same was true of highlevel executives in the private sector. On the whole, there was a somewhat 'promiscuous' relationship between the public and private sectors. SFF participation in these service structures seems to have fallen off towards the late 1990s, however. In place of the SFF, the main interlocutor for CORFO and the industrial sector came to be a sectoral association of the SFF, the Association of Exporters of Manufactures (ASEXMA).

\section{(b) The regional and global level}

The non-Uruguayan organization most often mentioned in the SFF 1997-1998 annual report was MERCOSUR (it ranked fifth overall). This is rather different to the situation with LAFTA in 1966. When the references are compared between the two periods, other interesting differences emerge. In the 1990s, patterns of interaction between the SFF and the regional and global levels were not really directed at individual organizations so much as at free trade negotiations and treaties, a reflection perhaps of the fact that Chile had the most trade agreements of any country in Latin America, and that businesses were increasingly exportoriented. The space given over to trade (including MERCOSUR) in the annual report cited does not reflect the huge impact of this issue on the structure of the SFF. In the 1960s, the SFF acted as a 'messenger' in the negotiations: it was given the lists of topics to be negotiated, delivered them to the companies concerned and then relayed their responses to the government. ${ }^{9}$

\footnotetext{
${ }^{9}$ Interview with Hugo Baierlein Hermida, SFF external trade director.
}

In the $1990 \mathrm{~s}$, the negotiating format was far more complex: not only were almost all the issues on the table at once, but negotiations were going on with several different countries at the same time. This led to the creation of a whole new system of interaction with the State, one of the precedents for which was the 1997 partnership treaty with MERCOSUR containing timetables for tariff reductions across the board. Perceiving that an agreement with MERCOSUR was of strategic value, the SFF gave its technical and political support. The partnership negotiated by Chile with MERCOSUR also transcended commercial calculation. Business representatives and State technocrats worked closely together on the complex negotiations. Another important if less crucial aspect was growing collaboration among the region's firms by virtue of their participation in private-sector organizations or networks, usually centring on trade agreements or negotiations; these included the MERCOSUR Industrial Council and the Business Network for Hemispheric Integration (REIH). The growing interest in external trade led to the creation of new working groups in the SFF, and to the incorporation of a large network of company consultants and specialists.

Where services are concerned, there is a striking lack of references to external cooperation agencies in SFF documents. Although many were highly active in this field, they go virtually unmentioned. On the whole, the SFF showed a certain reluctance to become involved with them. It argued, for example, that it did not need funding from these organizations because it was operating as a private business, competing in the marketplace (largely with State financing). It is true that it had had little involvement with international agencies in the $1960 \mathrm{~s}$, but it is surprising that this situation should have continued as these organizations became increasingly active locally. Thus, for example, GTZ (German Agency for Technical Cooperation), ${ }^{10}$ one of the most influential development agencies in Chile, which specialized in assisting SMEs, acted not through the SFF but through ASEXMA. The SFF was considered to have a rather authoritarian conception of social relations and was seen as a defender of large companies, with little representation among SMEs. Representatives of two organizations that were important in the field of business services thought

\footnotetext{
${ }^{10}$ Deutsche Gesellschaft für Technische Zusammenarbeit.
} 
much the same: Eurocentro (financed by the European Union) and the IDB. ${ }^{11}$

One of the elements that most conflicted with world culture came to light during Augusto Pinochet's trial in the United Kingdom. As Tironi (1999, p. 59) points out, Pinochet's detention made many Chilean business leaders realize that globalization, formerly so idealized, could become a threat, and they quickly began to demonize it. Furthermore, Pinochet's detention showed that Chile was involved with the world not just economically but morally, politically and legally as well.

\section{Uruguay}

A comparison of the CIU organization chart of 1998 with that of 1966 shows that most of the committees operating in the 1960s had kept their names. However, some new issues had come to prominence, among them foreign trade. Although a Free Trade Area Advisory Commission already existed in 1966, it concerned itself almost exclusively with LAFTA. In 1998, by contrast, the External Trade Committee was considered to be of crucial importance for the sector, had a much wider range of activities and easily attracted the largest number of participants of any committee (35, against an average of 15). The Environment Committee, which was also new, was much less active, perhaps because the State had done very little work in this area, for which its Technical Advisory Committee on Environmental Protection (COTAMA) was responsible. Another committee that had not existed in the 1960s was the one responsible for relations with the 'interior' (the rest of the country outside the Montevideo area). To be represented nationwide was always a goal of the Chamber and one which has not yet been achieved, even though Uruguay is a relatively small country. Among the committees surviving from the 1960s was one concerned with science, technology and quality, perhaps because these issues, along with foreign trade, attracted a particularly large volume of services and support from international organizations. The Economic Affairs and Investment Unit also had a long track record. Apart from what COMCORDE had

\footnotetext{
${ }^{11}$ Interviews with Francesca Di Micco, in charge of the Eurocentro project; Vladimir Radovic, IDB representative in Chile; and Peter Palesch, director of the GTZ agency in Chile and coordinator for the whole of MERCOSUR.
}

done, the CIU did not have much research of its own. The 1990s brought a renewed interest in this type of activity, but the studies carried out were not focused on long-term policies, generally dealing instead with periodic indicators. Lastly, the Social and Employment Relations Committee also existed in 1966, but this was not a very active area for the CIU.

In 1998, the board of the Chamber included only a small number of professionals, something that did not sit well with its new service-oriented profile and indeed marked a change from its composition in 1966, when there were more professionals (CIU, 1998). Another interesting point is that in 1998, none of the board seems to have held public office. This was also a change from 1966, when at least two held government positions. In the two years considered, no board member had a foreign degree. If board members are assumed to be representative of the leading group of industrialists, it has to be said that their professional profile was weak, whether compared to the 1960 s or to the SFF. In the latter, not only did the number of professionals and managers increase, but so did the number of qualifications obtained abroad. In addition to having a weak professional profile, the membership of the CIU board was still constituted mainly by owners (of companies with little international exposure) rather than professional managers. It would seem that despite efforts at liberal reform, the new generation of Uruguayan business leaders still came from an institutional environment in which the premium was on social skills more than professional ones. This characteristic was mentioned in an ECLAC study, which argued that in Uruguay most contacts were initiated individually, highlighting the importance of relying on personal networks rather than on those backed by the State or any other organization (ECLAC, 1998). However, the profound impact of the crises and of trade liberalization on industry caused many large companies to disappear. Consequently, SMEs were better represented on the 1998 board, and this may have been an incentive for change. A sign of this was the election of new authorities in 1992, when several candidate lists were presented for the first time in 20 years. According to Zurbriggen (1999), almost 50\% of members participated in the election, an enormous increase on the $3 \%$ (about 50 members) that normally voted. New actors entered the scene.

\section{(a) The national level \\ One of the national organizations most often mentioned in the CIU 1998-1999 annual report was}


the Ministry of Industry, Energy and Mining (MIEM), although tariff and subsidy reductions meant that this was no longer the 'pressure point' it had formerly been. The reforms of the 1990s assigned this ministry the role of service coordinator and promoter of SME support programmes. Nonetheless, a significant proportion of companies did not see any advantage to participating in programmes related to the creation of export consortia or networks of different kinds, fearing excessive bureaucratization (ECLAC, 1998). Some went further and complained of "the Ministry's poor image". Another criticism, echoing Esser, Almer and others (1983), was of a lack of direction in competitiveness policies. There were even some who argued that "MIEM has no real existence", as it was only part of a clientelist party agreement: if a government of the white party was in power, the ministry would belong to the red party, and vice versa.

Another organization that was often mentioned was the Technological Laboratory of Uruguay (LATU). This was the country's leading technology laboratory, holding International Organization for Standardization (ISO) certification and acting in turn as a certification body for ISO standards. It was associated with quality and new technologies, thereby helping to give the CIU a 'modern' image. Among the organizations working with LATU were the Technological Management Centre (CEGETEC) and the National Business Support Service (SENAE), whose main mission was to provide smes with technical assistance and project implementation guidance. The third most frequently cited Uruguayan organization was parliament. As we saw earlier, the CIU had created a committee to deal with legislative issues. According to business people, parliament was generally ill-informed about the industrial sector and there were virtually no institutionalized channels for exchanging views. This committee sought to monitor legal issues relating to the sector and help CIU member associations present their positions or alternative proposals to parliamentarians.

\section{(b) The regional and global level}

Although the CIU 1966-1967 annual report made more mention of local organizations than of international or regional ones, the latter gained greatly in prominence over the 1966-1998 period. Among non-Uruguayan organizations (and indeed in total), the most frequent mentions were of MERCOSUR. However, Uruguayan business leaders did not show much interest in participating in the integration process (Birle, Imbusch and Wagner, 1994). It is true that the
CIU was quick to accept MERCOSUR, but this owed more to a feeling that there was no alternative than to a true regionalist spirit or export ambitions. When companies, after decades of protection, grasped the harsh realities of lower tariffs, the Chamber's optimism gave way to qualified support. Liberalization increased the vulnerability of Uruguayan industry and reduced the Chamber's revenues, since fewer certificates of origin were issued. One channel of participation in the process was the Sectoral Commission for MERCOSUR (COMISEC). Outside the State arena, there was also the MERCOSUR Industrial Council (CIM), which provided the Chamber with an international outlet for its views. Other than this, the State played a more preponderant role in the new trade negotiating format than it had in the 1960s.

Although MERCOSUR had a powerful impact on Uruguayan industrial structures, some international bodies influenced the organizational structure of the CIU and were crucial to its transformation into a service provider in the early 1990s. The 'trigger' for this was a project financed by the United Nations Industrial Development Organization (UNIDO) in 1992, which led on to an IDB-financed project to study trade opportunities in Argentina, Brazil and Mexico. ${ }^{12}$ This project left the CIU with two units supported by IDB funding: the Business Information Service (SIPE) and a training UNIT called the Industrial Institute for Higher Studies (IIES). The IDB became one of the CIU's leading sources of support, going on to finance technical assistance and consultancy services for project implementation (CEGETEC) and the formation of 'export consortia'. The tie-up with the IDB also operated on other levels, as a number of executives (technical experts) working in the CIU were in receipt of direct or indirect financing from the bank. IDB support did not come all at once, however. In view of the Chamber's weaknesses as a service provider, IDB programmes included an 'institution-building' item intended to improve the technical capacity of the CIU. Another institution that also targeted businesses with SME programmes in Uruguay was GTZ. Its first project with the CIU began in the early 1990s with the establishment of an SME support division. Like the IDB, GTZ included 'institutional support' in its projects, something that was of a piece with its policy

\footnotetext{
${ }^{12}$ Interview with Roberto Villamil, general manager of the CIU.
} 
of turning industry associations into service-oriented organizations. ${ }^{13}$

In Uruguay, as in Chile, the European Union had development networks and programmes. One of them, in which the CIU (unlike the SFF in Chile) played an important role, was the Eurocentro, which was established within the Chamber itself and actively fostered trading ties between Uruguay and the European Union. In this way, the CIU also developed links to the Technological Information Promotion System (TIPS), associated with the United Nations Development Programme

\section{VI}

\section{Conclusions}

This study has examined the process of institutional change in Chile and Uruguay as experienced through industrialists' associations. The hypothesis put forward here concerning an increase in the influence of global institutions and organizations in the 1990s has been confirmed. In the 1960s, world culture was already establishing a presence through international organizations that spread organizational models based on a rational culture. Support for 'planning' was associated in Chile and Uruguay with the promotion of a positive view of technical disciplines, the State and democracy. This outlook was embodied in developmentalism and ECLA, also strong promoters of regionalism, and had great influence on industrialists, especially in Chile. During the military interlude, the role of the State, democratic values and regionalism went into abeyance. The process of institutional change through market reforms continued, however, particularly in Chile. In the 1990s, with democracy re-established in both countries, there was a new influx of world culture in which international bodies had a stronger presence, the core issues now being external trade and competitiveness. This highlighted the importance of regionalism, whose main manifestation was MERCOSUR. In both countries, there were also changes in methods of interaction with the State, the most important player at the national level. Interaction

\footnotetext{
${ }^{13}$ Interview with Alfredo Echegaray, IDB sector specialist in Uruguay.
}

(UNDP), and to the Development Information Network (DEVNET), and became the official representative for the 'REFA methodology', among other things. This started with a GTZ-financed project whereby REFA International ${ }^{14}$ helped to organize the CIU educational division. The appearance of the Chamber's corridors was very different in 1998 to that of 1966. Many office doors bore the name of an international organization or an externally funded project. This meant not just new sources of financing, but greater influence for nonUruguayan sources of legitimation.

of a subordinate, corporative nature gave way to a relationship based increasingly on services. These are the similarities, which are largely attributable to systemic changes.

The differences, for their part, have much to do with institutional peculiarities rooted in each local institutional environment. 'Clientelism' and 'caudillism' predominate in Uruguay, something that is associated with a permanent fragmentation of public policies and dependence on individual initiatives dominated by only loosely coordinated networks. This might explain the weak position of technical specialists and centralizing agents, ultimately resulting in a weak position for the State. Although the State remains very important for industrialists, its presence has diminished. This has opened the way to a larger role for international organizations and the "NGO-ization" of the CIU. In Chile, the technocratic approach has been maintained and strengthened, providing the basis for an elitism which has created points of contact between the SFF and the State. This is of a piece with the traditional tendency towards centralization via a 'big State' or a 'strong State'.

The present study shows that, for all their increasingly liberal rhetoric, Chilean business leaders have been resuming their close ties with the State, except that there has been a change in their substance.

\footnotetext{
14 REFA International is a German federal association for business organization and training.
} 
Regarding the relationship between Chile and the world, we would say that its position as a 'model country' is nothing new, since it already had a great affinity to world culture in the 1990s. It would be a mistake to conclude that Chile was wholly attuned to 'appropriateness', however. There are elements of confrontation with world cultural values, forcing the SFF to grapple with less hierarchical and elitist conceptions of society; this may be the reason for its limited contact with international organizations, which are viewed with some suspicion. The reaction of the SFF to the Pinochet issue is also part of that confrontation. Oddly enough, this is leading it to strengthen its ties with the State, which is seen as an 'ally' when dealing with the economic and cultural aspects of globalization.
In this respect, the Uruguayans are at an advantage. 'Caudillism' and 'clientelism' bring a horizontality that fits better with ideas of what is 'appropriate' in global culture. They provide other possibilities for interaction between individuals and elites, both for citizens (in relation to the State) and in the private sector. It is not for nothing that when countries are ranked for their democratic character, Uruguay continues to come out near the top. In summary, if world culture is accepted as an ideal type, it might be said that Chile has a technocratic advantage over Uruguay, but that its elitism is a disadvantage. Uruguay, with its more horizontal, democratic culture, is still better placed in this respect, although it must be said that Chile is quickly closing the gap.

(Original: Spanish)

Apey Rivera, M.A. (1988): Historia de la Sociedad Nacional de Agricultura, Santiago, Chile, Sociedad Nacional de Agricultura.

Arriagada, G. (1970): La oligarquía patronal chilena, Santiago, Chile, Ediciones Nueva Universidad.

Astori, D. (1980): Los industriales y la tecnología: un análisis de las actitudes de los empresarios uruguayos, Montevideo, Interdisciplinary Centre for Development Studies.

Beretta Curi, A. and A.G. Etcheverry (1998): Empresarios y gremiales de la industria. Asomándonos a medio siglo de historia: de la Liga Industrial a la Unión Industrial Uruguaya (1879-1928), Montevideo, Chamber of Industries of Uruguay.

Birle, P., P. Imbusch and C. Wagner (1994): Los empresarios y la integración regional en América Latina, in P. Birle, P. Imbusch and others, Dos estudios sobre los empresarios y la integración regional, Montevideo, Friedrich Ebert Foundation.

Boli, J. and T.M. Georg (eds.) (1999): Constructing World Culture: International Nongovernmental Organizations since 1875, California, Stanford University Press.

Campero, G. (1984): Gremios empresariales en el período 1970-1983, Santiago, Chile, Latin American Institute of Transnational Studies (laits).

Ceppi, M. de L., B. Sanhueza and others (1983): Chile: 100 años de industria 1883-1983, Santiago, Chile, Manufacturers Association (sff).

CIDE (Comisión de Inversiones y Desarrollo Económico) (1989): Informe sobre la administración pública, Reforma del Estado series, No. 2, Montevideo, Instituto Nacional del Libro.

CIU (Chamber of Industries of Uruguay) (1966): Memoria anual 1966-1967, Montevideo.

(1998): Memoria anual 1998-1999, Montevideo.

ECLAC (Economic Commission for Latin America and the Caribbean) (1998): Apoyo al Ministerio de Industria, Energía y Minería (MIEM) para la elaboración de estudios en el sector industrial, uru/96/011 Project, Santiago, Chile.

El Día (1966): "Día de la industria" supplement, 12 November.
El Mercurio (1966): Aporte de 775 millones de dólares de la Alianza para el Progreso, Santiago, Chile, 16 March.

Empresa (1968): year XII, No. 76, August.

Esser, K., G. Almer and others (1983): Monetarismo en Uruguay: efectos sobre el sector industrial, Berlin, German Development Institute (gdi).

Faroppa, L.A. (1982): Políticas para una economía desequilibrada: Uruguay 1958-1981, Temas del siglo, Montevideo, Ediciones de la Banda Oriental.

Ferrando, L. (1989): Gremiales empresariales, Unión Industrial Uruguaya. Textos auxiliares para el estudio de la historia, Montevideo, Facultad de Humanidades y Ciencias de la Educación, Universidad de la República.

Finch, E.A. (1973): The Politics of Regional Integration: a Study of Uruguay's Decision to Join LAFTA, Monograph series, No. 4, Liverpool, University of Liverpool.

Hardt, M. and A. Negri (2000): Empire, Cambridge, Harvard University Press.

Hart, O. (1995): An economist's perspective on the theory of the firm, in O. Williamson (ed.), Organization Theory: From Chester Barnard to the Present and Beyond, Oxford, Oxford University Press.

Hettne, B. and A. Inotai (1997): The new regionalism: implications for global development and international security, Research for Action, Helsinki, World Institute for Development Economics Research, United Nations University.

Jacob, R. (1981): Breve historia de la industria en Uruguay, Montevideo, Fundación de la Cultura Universitaria.

Kirsch, W.H. (1977): Industrial Development in a Traditional Society: The Conflict of Entrepreneurship and Modernization in Chile, Gainesville, The University Presses of Florida.

La Mañana (1966): Síntesis, No. 102, 23 May.

March, J.G. and J.P. Olsen (1989): Rediscovering Institutions. The Organizational Basis of Politics, New York, The Free Press.

MIEM (Ministry of Industry, Energy and Mining) (1997): 90 años, 1907 - 12 de marzo, 1997, Montevideo. 
Mikesell, R.F. (1961): The movement toward regional trading groups in Latin America, in A. Hirschman (ed.), Latin American Issues. Essays and Comments, New York, The Twentieth Century Fund.

Muñoz Gomá, O. (1997): Políticas públicas para un desarrollo competitivo, Santiago, Chile, Editorial Universidad de Santiago.

Powell W.W. and P.J. DiMaggio (eds.) (1991): The New Institutionalism in Organizational Analysis, Chicago, The University of Chicago Press.

Rosenau, J.N. (2003): Distant Proximities. Dynamics beyond Globalization, Princeton, Princeton University Press.

Selznick, P. (1949): TVA and the Grass Roots: a Study in the Sociology of Formal Organizations, vol. 3, Berkeley, University of California Press.

SFF (Sociedad de Fomento Fabril) (1966): Memoria anual, 19961967, Santiago, Chile.

(1998): Memoria anual, 1998-1999, Santiago, Chile.

Silva, E. (1996): The State and Capital in Chile, Business Elites,
Technocrats, and Market Economics, Colorado, Westview Press.

Silva, V. (2001): Estrategia y agenda chilena en los años noventa, Comercio internacional series, No. 11, LC/L.1550-P, Santiago, Chile, Economic Commission for Latin America and the Caribbean (eclac). United Nations publication, Sales No. S.01.00.G.94.

Stolovich, L., J.M. Rodríguez and L. Bértola (1996): El poder económico en el Uruguay actual, Montevideo, Centro Uruguay Independiente.

Tironi, E. (1999): La irrupción de las masas y el malestar de las elites: Chile en el cambio de siglo, Santiago, Chile, Editorial Grijalbo S.A.

Zeitlin, M. (1984): The Civil Wars in Chile (or the Bourgeois Revolutions that Never Were), Princeton, Princeton University Press.

Zurbriggen, C. (1999): Las organizaciones empresariales en la escena de los 90, Working Paper, Montevideo, Instituto de Ciencia Política (ICP). 